\title{
Macroeconomic Policy, Stimuli, Aid and Budgeting: What Options?
}

\author{
Ricardo Gottschalk with Laura Bolton*
}

\begin{abstract}
Developing countries are being severely hit by the global crisis. However, the ability of different countries to respond varies considerably. $A$ number of middle-income countries have foreign reserves and fiscal space to mitigate the effects of the crisis, but low-income countries (LICs) do not have the resources to cushion the macroeconomic shock. This article finds that, among LICs, sub-Saharan African aid-dependent countries are particularly vulnerable. It recommends that developing country governments should use a range of economic and financial policy instruments to combat the downturn, and highlights what in previous crises has worked well, e.g. counter-cyclical mechanisms, which helped protect the most vulnerable, and large-scale external financing packages, critical in helping countries recover fast. Given the nature of the current crisis, and the fact that different shocks tend to overlap, the article argues that the international community should seek to develop a more integrated approach to dealing with shocks.
\end{abstract}

\section{Introduction}

Developing country financial crises in the 1990 s and early 2000s were significant. However, in many cases, recovery tended to be relatively fast, because developing countries could export their way out of the crisis. The global nature of the current financial crisis and its wide ranging impacts through multiple channels such as trade, finance and remittances, greatly reduces the options available.

This article examines what policy choices developing countries have to protect their national incomes and mitigate the impacts on the poor. It addresses questions such as: how able are countries to respond to the crisis? If exports are not an option in the short term, how much fiscal space do they have to stimulate their economies and support expansion of social protection mechanisms? Where the latter do not exist or are too precarious, are there effective ways to protect the poor and the most vulnerable? What is the best expenditure strategy to ensure that recovery is sustainable in the long term?

The article highlights the fact that although virtually all developing countries have been hit by the global financial crisis, their ability to respond differs, in some cases quite considerably. A number of middle-income countries have foreign exchange and fiscal space to mitigate the effects of the crisis, but low-income countries (LICs) do not have the resources to cushion the macroeconomic shock. The article also argues that, given the limited choices available due to the global nature of the crisis, countries have to find innovative ways out of the crisis. The article also highlights what in previous crises has worked well - for instance, counter-cyclical mechanisms such as automatic stabilisers, which helped protect the most vulnerable, and largescale external financing packages, which have been critical in helping countries recover fast.

The article first describes the impacts of the crisis on different groups of developing countries. It next discusses the different degrees of preparedness among countries, and then what policy choices are available. It ends with a set of policy recommendations for the international community to help developing countries weather the downturn.

\section{Crisis impacts: what channels matter most?}

Developing countries have been hit by the financial crisis through different channels: financial (private capital), trade, aid and 


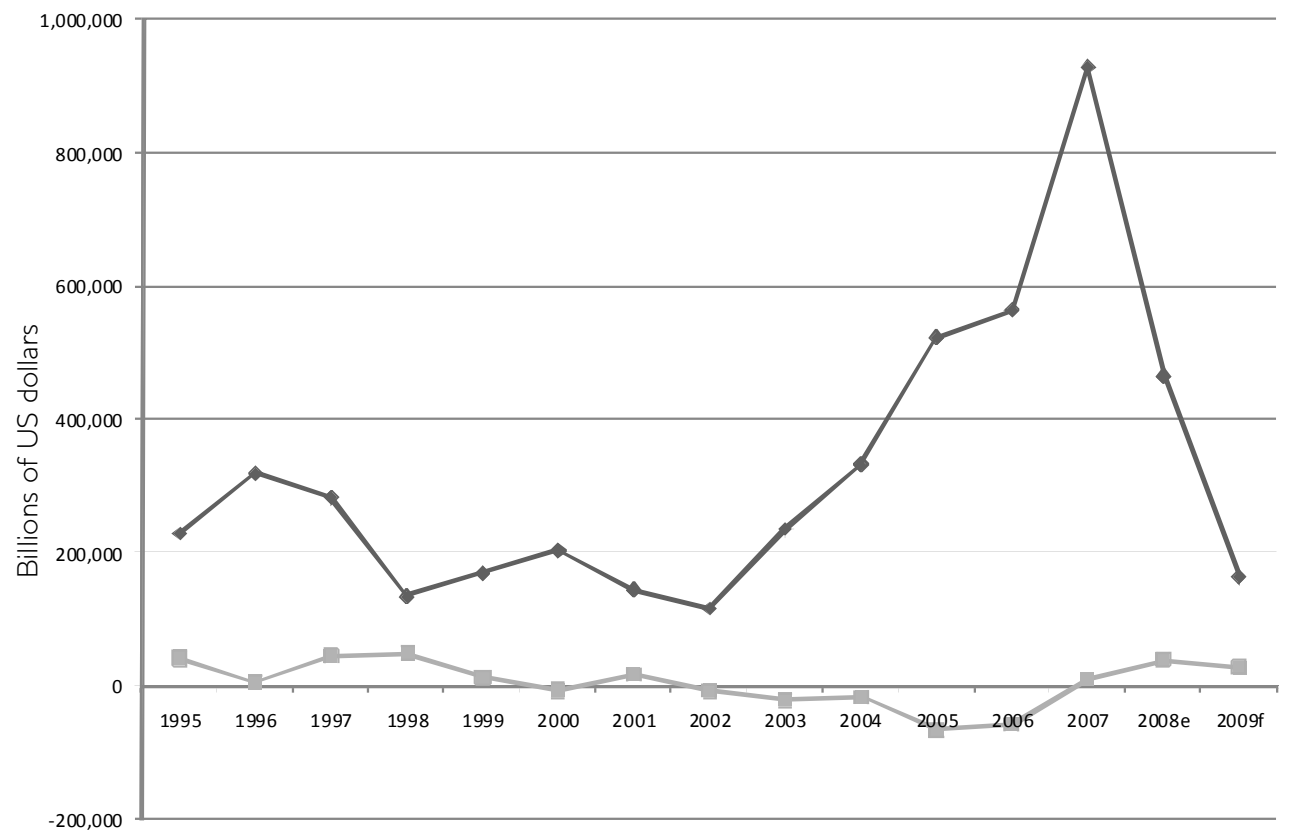

$\multimap$ Private flows, net $\quad-$ Official flows, net

Source Authors' elaboration, based on data from the Institute of International Finance (IIF).

${ }^{*}$ Flows to 28 emerging economies from emerging Asia, Latin America, emerging Europe and Africa/Middle East. e: estimate; f: forecast

remittances (transfers of money from workers abroad to their home countries). However, developing countries form a very large and heterogeneous group. They differ from each other by how they are integrated in the world economy and their initial macroeconomic conditions. Thus, for each country or group of countries, some channels matter more than others. Moreover, countries' initial conditions and response capacity can also change very quickly, depending on how exposed the economy is and measures undertaken in response to the previous financial crises.

The financial channel has already affected those emerging market economies that have recently attracted large amounts of private capital. The capital reversal has been sudden and ample, and is forecast to intensify in 2009 (see Figure 1), which also shows that official flows operate in a counter-cyclical way: every time private flows recede official flows increase, and vice-versa.

Moreover, the cost of raising international capital has gone up, as emerging market's sovereign (government-issued) bonds are seen as more 'risky' by international investors. The effects on the domestic economies of emerging markets have varied depending on which sectors were more exposed to foreign capital. In Korea, banks had borrowed heavily and faced difficulty in renewing international bank loans, with knock on effects on domestic credit markets. In Brazil, non-financial large companies had large foreign debts. Also, some companies were on the wrong side of hedging positions - that is, betting on further domestic currency appreciation. This, in turn, has reduced domestic banks' willingness to lend to these companies. In Eastern Europe, many countries have large current account deficits and thus are having to consider resorting to IMF loans. In early 2009, the IMF had already approved emergency loans to Hungary, Ukraine, Belarus and Latvia (IMF 2009c).

Although emerging economies were initially affected by the financial channel, as recession has set in within the developed world, global trade has collapsed (particularly since the last quarter of 2008), thereby strongly affecting 


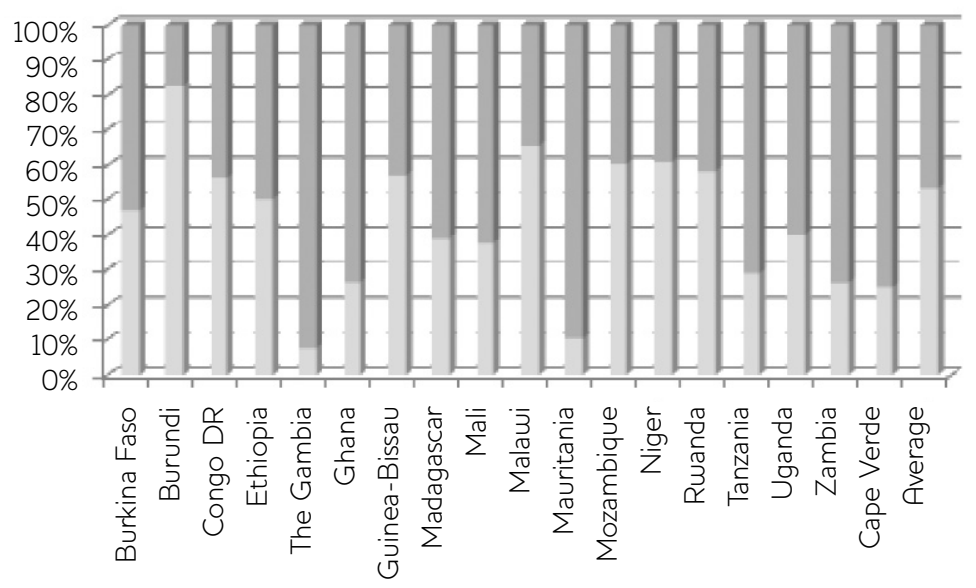

Source Authors' elaboration based on various IMF country reports.

${ }^{*}$ Average calculations based on 19 sub-Saharan African countries identified as aid-dependent.

economic performance in emerging economies, especially from East Asia where exports are a major driver of growth. The World Economic Outlook of April 2009 reports a decline in developing Asia output growth from 10.6 per cent in 2007 to 7.7 per cent in 2008. For all developing countries, the growth decline was less pronounced - from 8.3 to 6.1 per cent.

Less exposed to international capital flows, lowincome countries have been affected by reduced external demand and falling commodity prices. ${ }^{1}$ Thus, the real channels have been of far greater importance.

Unlike in emerging economies where the banking systems tend to be susceptible to the international capital flows, the financial sectors in LICs are less exposed to these flows.

Therefore, despite the international crisis, on the whole banks remain solid (with high capital ratios and low non-performing loan ratios) and maintain their lending at pre-crisis levels.

(However, as growth slows down in LICs due to the trade shock, banks' balance sheets in these countries will likely deteriorate and therefore affect credit supply to the economy.)

Notwithstanding the above, the following remarks are in order. First, a few LICs are exposed to private flows due to capital account liberalisation, with foreign credit feeding domestic markets. A recent IMF document reports that this has been the case in countries such as Kenya, Nigeria, Ghana, Uganda and Zambia. ${ }^{2}$ Also, some countries such as Ghana and Sri Lanka have been able to raise finance in the international capital markets (IMF 2009b: 9). These countries are therefore vulnerable to the capital flows reversal.

Second, trade finance to low-income countries declined by 18 per cent in the final quarter of 2008, thereby affecting countries such as Lesotho, Pakistan and Sri Lanka (IMF 2009b: 12).

Third, FDI to low-income countries is forecast to decline sharply - by nearly 20 per cent in 2009 (IMF 2009b). The amount of FDI that LICs attract is, in a considerable number of cases, significant when measured as a proportion of their GDPs. ${ }^{3}$

In addition to the trade shock and reduction in private capital flows, LICs are also suffering from declining remittances, which in some cases are larger than their export values and account for a large portion of their external financing needs. For the year 2009, a World Bank study forecasts remittances to sub-Saharan Africa (SSA) to fall by 1.3 per cent (Ratha et al. 2008). Remittances help a country meet its foreign exchange needs, but also have a critical micro dimension, as they constitute a vital income source for households with relatives working abroad. Unlike in previous crises when remittances tended to counteract the worst effects, this time their decline is reinforcing the plight of the poor. 


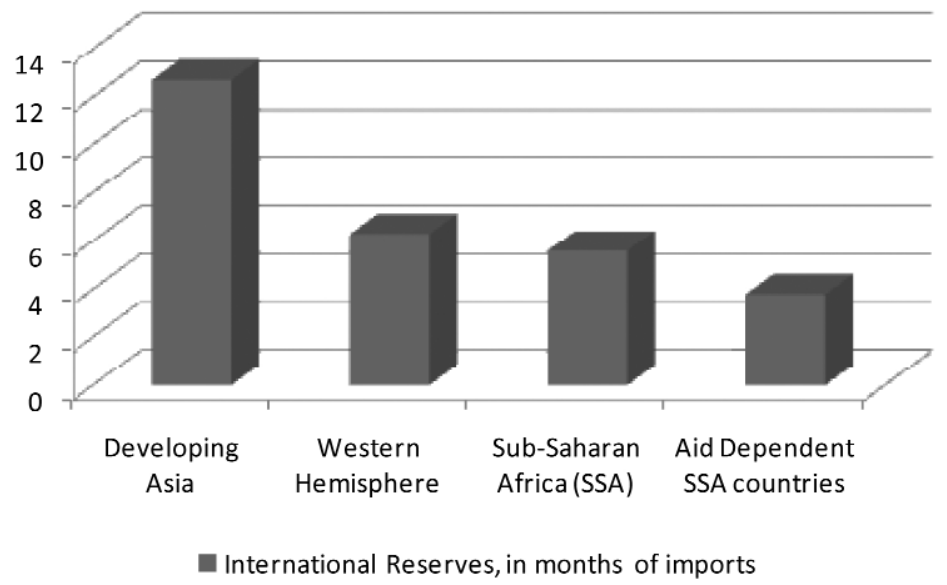

Source Authors' elaboration, based on IMF World Economic Outlook 2008 and various IMF country reports.

Finally, many low-income countries are aiddependent, which means they need foreign aid to meet their balance of payments needs and to finance a large part of their public expenditures ${ }^{4}$ - in some countries, foreign aid accounts for over 50 per cent of their total current expenditures (see Figure 2).

If aid flows do not increase or are curtailed, these countries will have to promote drastic adjustments, thereby reversing progress made in recent years, in terms of growth acceleration and poverty reduction. These countries have far lower foreign reserves compared with the emerging economies (Figure 3). In some countries, reserves have been already depleted due to the oil and food shocks, and the fact that little or no additional official assistance was made available to help them deal with such shocks.

\section{How prepared are developing countries to withstand the financial crisis?}

A country's ability to respond to the crisis differs considerably. Many emerging economies in Latin America and Asia, which have suffered from volatile international capital flows (see Figure 1), have learned to reduce their exposure to shocks and build capacity response by undertaking cautionary fiscal policy, reducing public debt, accumulating foreign reserves and adopting more flexible exchange rate regimes. As a consequence, they are in a stronger macroeconomic position and have some room to draw their own policy responses to minimise the economic and social effects of the crisis.
However, their starting points and amount of progress made have been uneven. In Latin America, despite a good record in recent years, countries such as Brazil still have somewhat limited space for expansionary fiscal policy, because of initially large public debt. Other countries such as Chile and Peru benefited from the recent primary commodity boom and saved a substantial portion of the windfall (Gottschalk and Prates 2006). In Asia, countries such as Malaysia and Thailand have historically maintained fiscal balance and thus have more power to implement large stimulus packages.

China's large-scale stimulus package has been widely announced, but many other Asian economies such as Singapore, South Korea and Taiwan also have fiscal space and are undertaking strong expansionary policy (see UN-DESA 2009; The Economist 2009). On the monetary front, the level of private savings, relatively low in Latin America but high in East Asia, is another key difference among countries. In principle, this gives monetary policy in Asia more power to stimulate domestic private spending (The Economist 2009).

For Asian countries, expansionary fiscal and monetary policies to stimulate domestic demand are critical to compensate for the sharp slowdown in exports, on which they are heavily dependent. International reserves are an additional policy tool, which can be used to help avoid excessive depreciation in the domestic currency, and thus negative impacts on financial and non-financial companies facing large currency mismatches in their balance sheets. Also, foreign reserves can be 


\begin{tabular}{|c|c|c|c|c|c|c|}
\hline Country/Group & $\begin{array}{l}\text { Debt } \\
\text { as \% GDP }\end{array}$ & $\begin{array}{l}\text { CA balance } \\
\text { as } \% \text { GDP }\end{array}$ & $\begin{array}{l}\text { Reserves in } \\
\text { months of } \\
\text { imports }\end{array}$ & $\begin{array}{l}\text { Fiscal deficit } \\
\% \text { GDP }\end{array}$ & $\begin{array}{l}\text { Main export } \\
\text { as } \% \text { total Xs }\end{array}$ & $\begin{array}{l}\text { Vulnerability } \\
\text { Index }\end{array}$ \\
\hline Burkina Faso & 19 & -11.5 & 5.4 & -5.7 & 0.715 & 0.257 \\
\hline Burundi & 127 & -12 & 3.3 & 0.5 & 0.246 & 0.518 \\
\hline Cape Verde & 55 & -11.6 & 3.4 & -0.7 & 0.489 & 0.406 \\
\hline Congo DR & 87 & -10.7 & 0.4 & -0.7 & & 0.588 \\
\hline Ethiopia & 11 & -4.3 & 1.5 & -3.1 & 0.328 & 0.376 \\
\hline The Gambia & 44 & -12.1 & 3.8 & 0.2 & 0.256 & 0.376 \\
\hline Ghana & 37 & -9.8 & 1.7 & -9.1 & 0.251 & 0.446 \\
\hline Guinea-Bissau & 235 & 7 & 7.4 & -10.3 & & 0.333 \\
\hline Madagascar & 25 & -27.4 & 2.5 & -2.8 & 0.141 & 0.527 \\
\hline Malawi & 17 & -2.9 & 1.9 & -3.4 & 0.138 & 0.354 \\
\hline Mali & 22 & -7.5 & 5.4 & -3.1 & 0.487 & 0.231 \\
\hline Mauritania & 57 & -8.6 & 3.4 & -2.0 & 0.686 & 0.385 \\
\hline Mozambique & 52 & -11.3 & 4.2 & -3.8 & 0.629 & 0.361 \\
\hline Niger & 14 & -9.7 & 3.4 & -1.0 & 0.632 & 0.331 \\
\hline Rwanda & 15 & -9.5 & 4.9 & -1.5 & 0.215 & 0.260 \\
\hline S. Tome Principe & 70 & -36.1 & 6.2 & & 0.872 & 0.484 \\
\hline Sierra Leone & 17 & -6.4 & 3.4 & 25.2 & & 0.310 \\
\hline Tanzania & 34 & -9.7 & 4.3 & -4.1 & 0.259 & 0.318 \\
\hline Uganda & 13 & -7.7 & 6.4 & -1.0 & 0.199 & 0.171 \\
\hline Zambia & 6 & -5.5 & 3 & -0.6 & 0.711 & 0.306 \\
\hline SSA aid dependent & 47.9 & -10.4 & 3.8 & -3.0 & & 0.367 \\
\hline All LICs & 48 & -7.7 & 4.2 & & & 0.327 \\
\hline SSA & 55 & -7.7 & 4.3 & & & 0.333 \\
\hline Asia & 37 & -6.7 & 4 & & & 0.313 \\
\hline
\end{tabular}

Source Authors' elaboration, based on data from IMF (2009b), IMF country reports, and UN International Trade Statistics Yearbook 2007.

*The vulnerability index is based on three macroeconomic indicators: debt to GDP ratio, current account deficit and level of reserves in months of imports. The data are based on IMF projections for 2008.

†Fiscal data are from various IMF country reports for the year 2007; country export data are for the latest year available in the UN International Trade Statistics Yearbook 2007.

used to finance larger current account deficits arising from expansionary fiscal and monetary policies. However, while in some countries reserves reflect past current account surpluses (e.g. China, Korea, Malaysia), in others such as India these are mainly 'borrowed reserves' - that is, reserves resulting from large net positive capital flows despite the occurrence of large current account deficits (Griffith-Jones and Ocampo 2008). For the latter group, the room for expansionary policies is considerably more limited. 
Figure 4 Vulnerability index

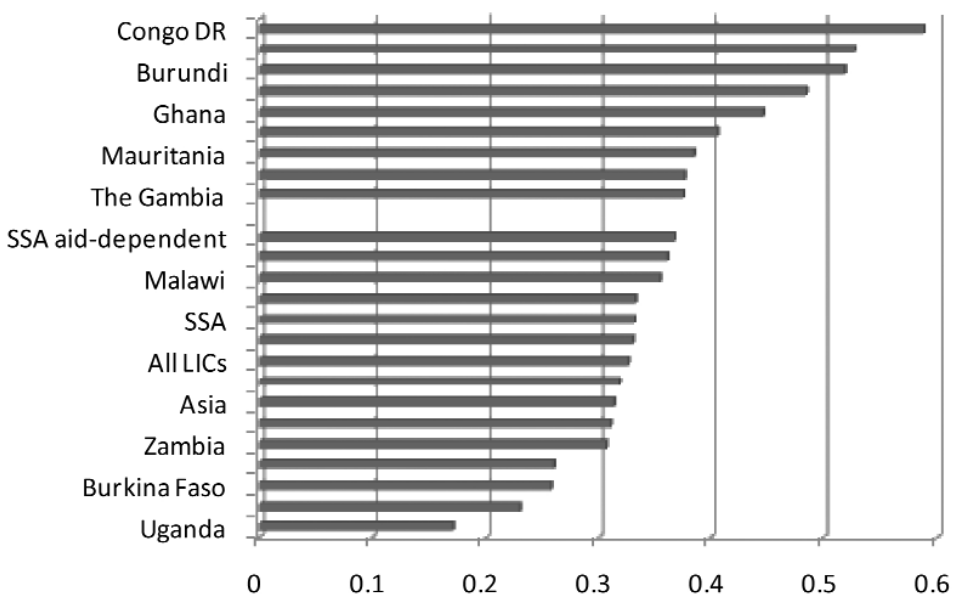

Source Authors' elaboration, based on data from IMF (2009b).

*The vulnerability index is based on three macroeconomic indicators: debt to GDP ratio, current account deficit and level of reserves in months of imports. The data are based on IMF projections for the year 2008.

\subsection{What about low-income countries?}

In contrast to the emerging economies, lowincome countries do not have their own resources to smooth consumption and support recovery. Table 1 displays a number of vulnerability indicators for LICs as a whole, for SSA and Asian LICs, and for the aid-dependent countries in SSA. It shows that, for these groups of LICs, debt as a proportion of GDP is fairly high, the current account balance very large and level of reserves in months of imports, low. Table 1 also shows that SSA aid-dependent countries are particularly vulnerable, scoring poorly in each indicator. Moreover, it shows that the aid-dependent countries have a narrow export base - in many cases, their main export product accounts for over 50 per cent of their total exports.

Figure 4 shows a vulnerability index for all the 20 aid-dependent countries in SSA plus different groups of low-income countries. ${ }^{6}$

It can be seen from Figure 4 and Table 1 that, among the SSA aid-dependent countries, Congo DR, Madagascar and Burundi exhibit the highest level of vulnerability, due to high debt levels and large current account deficits. Uganda and Mali look the least vulnerable due to low debt levels, but their current accounts are very large.

In the past, aid-dependent countries have suffered from trade shocks, which led to deceleration or even decline in domestic economic activities, with effects on governments' commodities and tax revenues. In this context, aid tended to stand as a more resilient source of government receipts, thereby benefiting countries that relied heavily on aid to finance public expenditures. However, in the current crisis these countries have aid as a potential additional source of vulnerability, due to the uncertainties regarding the future trajectories of aid flows. If aid declines, they will suffer severe budgetary and balance of payments constraints.

A further vulnerability dimension associated with aid is that some countries, such as Mozambique, are highly dollarised, due to aid flows. A sharp currency depreciation following an external shock may benefit the government budget that relies heavily on aid, but the balance sheets from the private sector suffer a great deal. In some countries banking regulators learned from previous crises to put in place a regulatory framework aimed at reducing large currency mismatches in banks' balance sheets. However, it is far more difficult to avoid such mismatches among non-financial companies, which makes banks that lend to such companies exposed to credit risk.

A closely related notion to the concept of vulnerability is a country's capacity to respond, or the fiscal space it has to promote stimulus policies, as mentioned earlier. A World Bank (2008) study indicates that of 18 countries that 
Figure 5 Fiscal deficit of aid-dependent countries in SSA (percentage of GDP, 2007)†

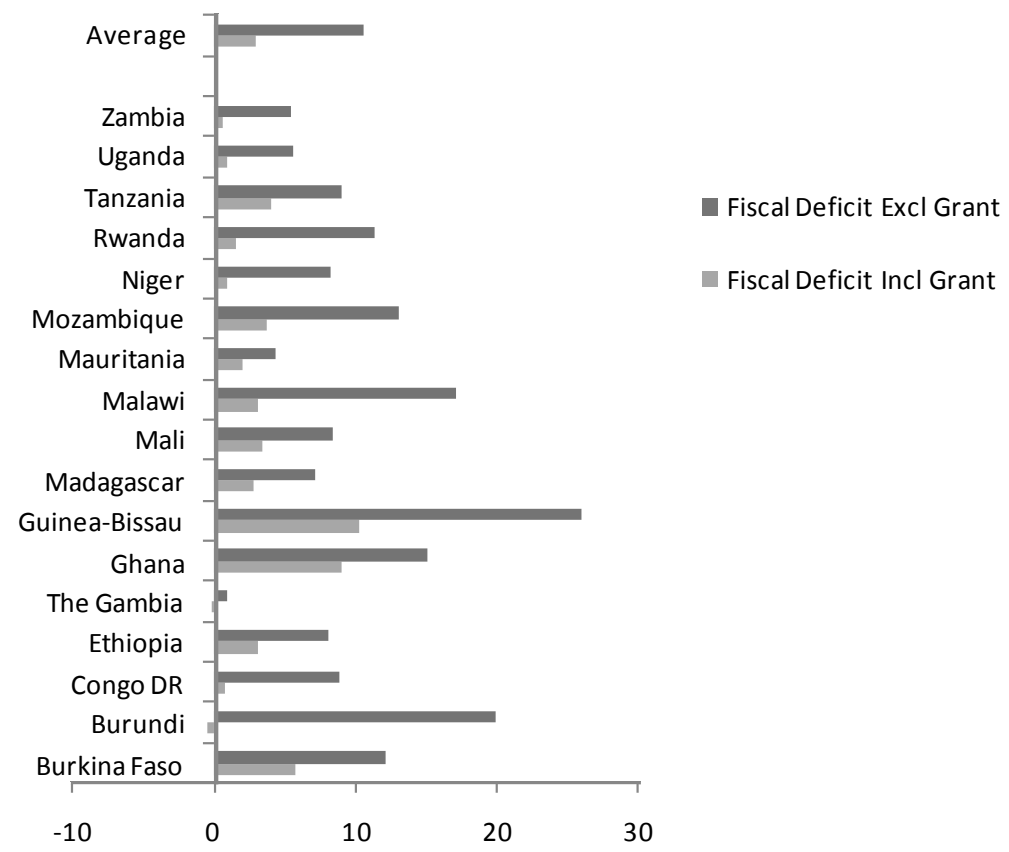

Source Author's elaboration, based on data from various IMF country reports. †Figures for Congo DR are from 2006.

we identify as aid-dependent in sub-Saharan Africa, ten have 'low fiscal space', while the other eight are considered either as having 'some fiscal space' or 'more fiscal space'. 'However, this may give a false sense of space, as it assumes aid will be forthcoming, which is far from guaranteed in the current crisis context. ${ }^{8}$ While Table 1 indicates that some countries have fairly small and therefore manageable fiscal deficits, Figure 5 shows how much larger these countries' fiscal deficits are when external grants are excluded - on average, the increase is from 3.0 to 10.6 per cent of the countries' GDPs. For them, such grants finance 27 per cent of their total fiscal expenditure. ${ }^{9}$

\section{How important is fiscal space in this crisis?}

In the 1990 s and early 2000 s, crisis-hit countries suffered massive currency devaluations, which caused severe balance sheet problems within their economies. At the same time, devaluation encouraged exports and thereby helped countries recover relatively fast. However, the global nature of the current crisis implies that external demand for developing country exports is declining. Therefore, these countries need to find alternative stimulus to support recovery. In this context, fiscal space becomes critical.

But, while stimulus policies can be made possible by fiscal space, they are not limited by it. For example, a country may have limited fiscal space, but still some room for monetary policy stimulus where inflation is declining (UN-DESA 2009). Due to falling fuel and food prices and the prospect of weaker levels of economic activity, inflation is projected to fall worldwide. Among developing countries, IMF projections indicate a decline in inflation from 10.4 per cent in 2008 to 5.5 per cent in 2009 (IMF 2009a). Moreover, countries can use financial policies to stimulate their economies. Thus, where fiscal space is limited, countries can:

- Consider alternative options such as monetary easing to stimulate the domestic economy, a response strategy that lower inflation allows.

- Strive to enhance the country's revenueraising capacity provided it does not harm domestic private demand.

- Use public banks to direct credit to the small and medium enterprises (SMEs) and the poor. 
- Use limited available public resources to target the poor (Ravallion 2008).

\subsection{What have we learned from the previous crises?}

We have learned that counter-cyclical mechanisms can be used to protect the poor and the most vulnerable. For example, during its 1998 crisis, Russia increased transfers through its pension system (Lokshin and Ravallion 2000). Unfortunately, such stabilisers are not a common feature, especially among low-income countries, but other mechanisms of a counter-cyclical nature or in the form of social protection may be available.

Price stabilisation funds constitute an important counter-cyclical mechanism for dealing with price shocks. These funds have been created by countries where total government receipts are overly dependent on commodity revenues, and therefore bound to exhibit volatile behaviour. Angola's Oil Reserve Fund, Burkina Faso's Cotton Support Fund, Chile's Copper Compensation Fund and Nigeria's Excess Crude Account are a few examples of funds that have been created to help smooth out governments' expenditures over time. Burkina Faso's fund played an important role in the past when cotton prices fell sharply in 2001-02 (See IMF 2002). Drawing on its copper fund, Chile is currently implementing a large fiscal stimulus package, designed to take the form of a 10 per cent increase in public expenditure in 2009, nearly half of it targeted to public works and handouts for the most vulnerable (Martinez 2009). Unfortunately, export commodity dependent countries that have such funds in place are few, making external assistance to deal with shock indispensable.

Similar to automatic stabilisers and stabilisation funds, social protection mechanisms are not widespread or with extensive coverage in the developing world, but a few cases stand out. Brazil and Mexico have successful cash transfer programmes that can be scaled up to protect those failing into poverty. Countries lacking such mechanisms can invest in infrastructure and undertake public work programmes (Ravallion 2008). Previous crises have also shown that the most vulnerable were the least likely to adopt effective coping strategies, indicating the need for targeted use of limited public resources. This requires adaptability and flexibility in terms of instruments available. ${ }^{10}$
At the same time, maintaining public investments is also very important for sustained recovery. In previous crises, these were drastically reduced, thereby undermining postcrisis long-term growth. Research by the National Institute of Economic and Social Research shows that fiscal stimulus spent on productive investment raises the level of output by 1.5 per cent in the long term (Barrell et al. 2009). To address the potential tension between short-term social needs and long-term growth, financing from regional multilateral banks and other types of regional funds (possibly by larger countries with higher spending capacity) might be a possible way forward. It could be made available for public investment, thereby helping free up domestic budgetary resources for poverty alleviation.

Previous crises have also shown that IMF-led financial packages can play a critical role in helping avoid too deep a crisis and supporting rapid recovery (as in Mexico's crisis of 1994-5 and Brazil's in early 1999). These packages were successful because resources were large, frontloaded and with reasonable conditionality attached.

\section{Policy recommendations}

Given the scale of the crisis, developing country governments should use not one but a range of economic and financial policy instruments, in addition to social protection mechanisms to combat the downturn and protect the poor. Where fiscal space is limited, space has to be sought elsewhere, for example in the monetary and financial policy areas. Space is particularly limited among LICs. Moreover, most such countries are under IMF sponsored Poverty Reduction and Growth Facility (PRGF) programmes, whose principal features include very low inflation targets, stress on budget balance, pro-poor focus but lack of pro-growth expenditure and absence of flexibility to deal with shocks (Gottschalk 2008). In this context, it is important that countries fight for space for stimulus policies, for example by increasing inflation and budget deficit targets. Countries with greater government capacity may be able to gain space but others, especially those emerging from conflict and therefore lacking capacity, need donor support for more flexibility in macroeconomic policy management to tackle the crisis. 
Post-September 2008 trends in international private capital flows to developing countries point towards a sombre picture, with sharp declines in all forms of flows, as seen earlier. This is compounded by declines in export revenues and private remittances as well. Thus, although this article focuses on country-level policies to address the crisis, external resources are critical.

At the London Summit in early April 2009, the G-20 re-affirmed its pledge to increase substantially the amount of financial resources to help developing countries cushion the effects of crisis. The promised amount is fairly large, of over U\$S1 trillion. If this promise materialises, a lot can be achieved in terms of helping countries mitigate the crisis' growth and poverty impacts. However, a number of issues and uncertainties stand in the way.

First, it is unclear how much of the promised resources are entirely new, and exactly what form these will take. Second, it is unclear the timeframe (and within it the speed) for their disbursement, which is a very important aspect, especially in view of the fact that the crisis effects are already being felt by the poor (see Hossain, this IDS Bulletin). Speed of resource disbursement is also important because it helps halt the feedback effects deepening the crisis. Third, it is still unclear as to through what institutions and mechanisms different types of promised resources will be disbursed. Moreover, no concrete plans have been made to reform existing mechanisms that, to date, have worked poorly. Finally, although promised resources seem large, most of it if eventually disbursed will likely be directed to the emerging economies. Of the total, US $\$ 50$ billion have been promised to LICs, but, again, with little said about when or how they will be disbursed.

Regarding the emerging economies, which in principle are the main beneficiaries of the promised resources, two issues arises. First, a large amount of the promised resources are intended to be channelled through the IMF. Although the IMF has created a new lending facility - the Flexible Credit Line (FCL), designed to frontload large funds with no strings attached, few countries will likely be eligible for this facility, given the pre-conditions these countries have to meet. This will leave out many emerging economies and middle-income countries, which will have to apply to the highconditionality type of IMF lending facilities. Disappointingly, although the G-20 represents a new, wider composition of forces and interests, this has not as yet been translated into new guidelines for an IMF policy shift in its lending facilities away from excessive emphasis on economic adjustment and towards more progrowth goals.

Second, it seems that, among developing countries, the emerging economies and other middle-income countries are those most affected by the decline in trade credit by international private banks. However, there is lack of clarity of how the promised increase in trade credit will be distributed between multilateral development banks and bilateral export credit agencies. This is an important point due to the latter's track record in allocating credit according to donor's trade interests.

But the LICs may stand as the losers of the London Summit, if no further action to help them is undertaken. Even if honoured, the Summit pledges will fall well short of the financing needs facing LICS, once the effects of the world slowdown are fully felt by this group of countries. Moreover, the Summit was vague as to how the promised concessional resources will be channelled. The spring meetings in late April did bring more concrete plans, including the intention by the World Bank to frontload its International Development Association (IDA) resources. However, more resources by the donor community should be made available to further enhance the IMF and World Bank concessional lending capacity and ensure funds are not lacking for post-crisis years. Moreover, no concrete plans to reform the IMF existing concessional lending facilities such as the PRGF and the Exogenous Shock Facility (ESF) have been laid out.

It is expected that, between the G20 meeting in April and the next meeting scheduled for the latter part of 2009, some of the action and policy gaps identified above are filled. Concretely, efforts should be made to:

- Expand the coverage of the IMF FCL, so that it can be accessed by a larger number of countries. In addition, the conditions attached to the traditional IMF lending facilities should be softened with a shift in emphasis towards 
growth recovery policies, as these facilities will be needed to assist those countries seeking for help but which will not eligible for the FCL.

- Clearly identify what institutions will be charged with channelling increased trade credit, and in doing so, preferably prioritise multilateral and regional banks over export credit agencies.

- Increase subsidy resources to the IMF-based funds that underpin the existing mechanisms, such as the ESF and the PRGF, for dealing with economic shocks. Moreover, it is important that these mechanisms are substantially reformed, to scale up resources made available, reduce conditionality and increase speed of disbursement.

- Support the creation of a new shocks financing architecture. While the existing shocks financing mechanisms should be modified now so that they are effective in responding to the current crisis, in the medium term the international community should seek to create a new shocks financing architecture that

\section{Notes}

* This article is based on an earlier version prepared for the UK Department for International Development (DFID). We are thankful to Andy Sumner and Neil McGulloch for their comments on an earlier version of this article. The usual caveats apply.

1 In the second half of 2008, non-energy commodity prices fell 38 per cent (World Bank 2009).

2 The IMF (2009b) considers LICs those countries that are PRGF eligible (78 countries in total). It therefore includes countries that, according to the World Bank classification, are considered middle-income countries instead.

3 IMF (2009b) projections for the LICs indicate that FDI to GDP ratio was at 7.0 in 2008. But this figure is a simple average and therefore biased upwards by high FDI to GDP ratios from small island countries.

4 Aid-dependent countries are defined here as those with average aid to Gross National Income (GNI) ratio of at least 10 per cent over the years 2000-06. This article identifies 20 sub-Saharan African countries as aid dependent: Burkina Faso, Burundi, Cape Verde, Congo DR, Ethiopia, The Gambia, Ghana, Guinea-Bissau, Madagascar, Malawi, Mali, Mauritania, Mozambique, Niger, Rwanda, Sao Tome and Principe, Sierra Leone, Tanzania, Uganda and Zambia. follows a more holistic approach. That is, an approach whereby a larger pool of funds is created and the same fund can be used for different types of shocks. In her article in this IDS Bulletin Hossain shows it is fairly common that external shocks overlap with national crises (linked to political conflict; natural disasters). A holistic approach also responds to demands from policy makers from countries that tend to be affected by multiple shocks simultaneously, as previous studies have found (see, e.g. Griffith-Jones and Gottschalk 2005).

- Complement the IMF and the World Bank roles with that of the regional development banks, in providing counter-cyclical lending, which can be used for public investment to enhance long-term growth. Also at the regional level, initiatives such as those from the East Asian countries to create a large pool of funds to combat the crisis should be expanded and replicated in other regions, where large financing capacity for pooling resources exist.

5 The grants to current expenditure ratio for 19 countries for which data are available are on average 54 per cent.

6 Our vulnerability index comprises three macroeconomic indicators: debt to GDP ratio, current account deficit and level of reserves in months of imports. The data are based on IMF projections for the year 2008. It is the simple average of a standard formula index (i.e. index $=($ actual-minimum $) /($ maximumminimum)), used among others by the UN for their Human Development Index (HDI). Other crisis-related studies have produced similar indexes for the closely related concept of fiscal capacity. The World Bank has produced a fiscal capacity index comprising debt/GDP, current account balance, international reserves and reversible capital inflows (see World Bank 2008). A recent UNESCO study also produced a fiscal capacity indicator comprising budget deficit, government debt to GDP ratio, revenue to GDP and aid to GDP. See UNESCO (2009).

7 The World Bank study categorises countries as having 'low fiscal space', 'some fiscal space' and 'more fiscal space' by averaging standardised indexes of debt/GDP, fiscal deficit, current account balance, international reserves and reversible capital inflows, over the years 2002-07. 
8 Fiscal space can be defined as the existence of fiscal room for increased spending, without jeopardising the government's fiscal sustainability (Heller 2005).

9 Author's calculations based on figures from various IMF country reports.

\section{References}

Barrell, R.; Holland, D. and Velde, D.W. (2009) 'A Fiscal Stimulus to Address the Effects of the Global Financial Crisis on Sub-Saharan Africa', unpublished draft paper, National Institute of Economic and Social Research and Overseas Development Institute

The Economist (31 January 2009) 'Troubled Tigers': 73-5

Gottschalk, R. (2008) The Effectiveness of the Macroeconomic Frameworks of the PRSPs for Growth and Poverty Reduction, paper prepared for United Nations Research Institute for Social Development under the project 'Poverty Reduction and Policy Regimes', April

Gottschalk, R. (2004) Emerging Markets Financial Crises and Country Poverty Profiles, report prepared for Department for International Development, March

Gottschalk, R. and Prates, D. (2006) East Asia's Demand for Primary Commodities - Macroeconomic Challenges for Latin America, G-24 Discussion Paper Series 39, February, New York: United Nations

Griffith-Jones, S. and Gottschalk, R. (2005) Compensatory Financing for Shocks: What Changes Needed?, report prepared for Department for International Development, August

Griffith-Jones, S. and Ocampo, J.A. (2008) 'Sovereign Wealth Funds: A Developing Country Perspective', paper prepared for the workshop on Sovereign Wealth Funds organised by the Andean Development Corporation, London, February

Heller, P. (2005) Understanding Fiscal Space, IMF Policy Discussion Paper, PDP/05/4, March, Fiscal Affairs Department, Washington DC: International Monetary Fund

IMF (2009a) World Economic Outlook April 2009, April, Washington DC: International Monetary Fund

IMF (2009b) The Implications of the Global Financial Crisis for Low-Income Countries, March, Washington DC: International Monetary Fund
10 For a review of different household coping strategies in crisis situations, see Gottschalk (2004).

IMF (2009c) 'IMF Helping Counter Crisis Fallout in Emerging Europe', IMF Survey Magazine, 14 January, Washington DC: International Monetary Fund, www.imf.org/ external/pubs/ft/survey/so/2009/INT011409A. htm (accessed 17 March 2009)

IMF (2002) Burkina Faso: Joint Staff Assessment of the Poverty Reduction Strategy Paper, Annual Progress Report, October, Washington DC: International Monetary Fund

Lokshin, M. and Ravallion, M. (2000) Welfare Impacts of Russia's 1998 Financial Crisis and the Response of the Public Safety Net, Washington DC: World Bank

Martinez, R. (2009) Chile Unveils \$4 Billion Anticrisis Stimulus Package, Reuters, 5 January

Ratha, D.; Mohapatra, S. and Xu, Z. (2008) Outlook for Remittance Flows 2008-2010: Growth Expected to Moderate Significantly, But Flows to Remain Resilient, Migration and Development Brief 8, 11 November, Development Prospects Group, Washington DC: World Bank

Ravallion, M. (2008) Bailing Out the World's Poorest, World Bank Policy Research Working Paper 4763, Washington DC: World Bank

UN-DESA (2009) World Economic Situation and Prospects 2009, New York: United Nations

UNESCO (2009) Global Crisis Hits Most Vulnerable, United Nations Educational, Scientific and Cultural Organization, http://portal.unesco.org/en/ev.phpURL_ID $=44687 \& U R L \_D O=D O \_T O P I C \& U$ RL_SECTIO (accessed 9 March 2009)

World Bank (2009) Swimming Against the Tide: How Developing Countries are Coping with the Global Crisis, background paper prepared by World Bank Staff for the G20 Finance Ministers and Central Bank Governors Meeting, Horsham, UK, 13-14 March World Bank (2008) The Global Economic Crisis: Assessing Vulnerability with a Poverty Lens, Washington DC: World Bank 